\title{
EARLY SELECTION OF ELITE PLANTS IN ASPARAGUS ${ }^{(1)}$
}

\author{
ENRIQUE LUIS COINTRY(2); FERNANDO SEBASTIÁN LÓPEZ ANIDO ${ }^{(2)}$; \\ ILEANA GATTI $^{(2)}$; VANINA PAMELA CRAVERO ${ }^{(2)}$; INÉS TERESA FIRPO ${ }^{(3)}$; \\ STELLA MARIS GARCÍA ${ }^{(3)}$
}

\begin{abstract}
In order to establish an efficient selection criterion the variability in three asparagus populations was evaluated defining the most important yield components and analysing its evolution along three growing seasons. The yield components, coefficient of variation $(\mathrm{CV})$ and the proportion of plants contributing to $80 \%$ of the total yield were estimated. The elite plants were selected by mean of total yield and clusters techniques. Multiple regression showed that spear number (SN) and spear weight (SW) were the most important yield components. In every population, total yield (TY) and SN showed the highest values of CV, independently of sex. $69 \%$ of the plants contributed to the $80 \%$ of the total yield in the first year while in the second and third year the contribution was 57\%. At the end of the third year, 17 plants were selected by the average of the total yield and 43 by clusters. It is suggested to select for SW in the first year, reducing in $68 \%$ the experimental material. In the second year, the selection for $\mathrm{SN}$ would reduce to $5 \%$ the plants to evaluate for total yield in the third year. In this way the selected plants are the same but the number of plants to evaluate is dramatically reduced along the years, therefore facilitating the breeders work.
\end{abstract}

Key words: asparagus, variability, elite plants, selection, plant breeding.

\section{RESUMO \\ SELEÇÃO PRECOCE DE PLANTAS-ELITE DE ASPARGO}

Com o fim de estabelecer um método de seleção eficiente, a variabilidade de três populações de aspargo foi avaliada, definindo-se os componentes de rendimento mais importantes e analizando-se a sua evolução durante três anos de cultivo. Os componentes de rendimento, o coeficiente de variação (CV) e a proporção de plantas que contribuíram para $80 \%$ do rendimento total foram calculados. Plantas-elite foram selecionadas através do rendimento total e técnicas de agrupamento "cluster". A regressão múltipla mostrou que o número e o peso médio de turiões foram os componentes de rendimento mais importantes. Em todas as populações, o rendimento total e o número de turiões apresentaram os valores mais altos de coefíciente de variaçao, independentemente do sexo. No primeiro ano $69 \%$ das plantas contribuíram aos $80 \%$ do rendimento total, enquanto que no segundo e terceiro anos a contribuição foi de $57 \%$. No final do terceiro ano 17 plantas (1.9\%) foram selecionadas pelo rendimento total e $43(4.8 \%)$ através da técnica deagrupamento. Recomenda-se selecioná-las pela massa média de turiões no primeiro ano, reduzindo em $68 \%$ a população inicial. No segundo ano a seleção seria feita pelo número de turiões, reduzindo a $5 \%$ as plantas que, no terceiro ano, serão avaliadas pelo rendimento total. Desse modo as plantas selecionadas são as mesmas, mas o número de plantas a avaliar no terceiro ano de cultivo é drasticamente reduzido, facilitando o trabalho do melhorista.

Palavras-chave: aspargo, variabilidade, plantas-elite, seleção precoce, melhoramento de plantas.

(1) Received for publication in December 11, 1998 and approved in March 30, 2000.

$\left.{ }^{2}\right)$ Department of Genetics, Experimental Field of the National Rosario University, CC 14-2123 Zavalla, Santa Fe, Argentina. E-mail: ecointry@fcagr.unr.edu.ar

(3) Department of Horticulture, National Rosario University. 


\section{INTRODUCTION}

The great heterogeneity of asparagus populations is due mainly to the typical dioecy of the species (HuYsKes, 1959; Ellison e SCHEer, 1959; MOON, 1976). This implies that plants will either have different yield or precocity than the rest of them, thus affecting total yield. The extreme variability for horticultural traits in the cultivated populations represents an important aspect that should be taken into consideration and even kept in the selection program of the species. Nevertheless, at present, the phenotypic uniformity is a fundamental objective in any breeding program for asparagus. BANNEROT et al. (1969) found that only $10 \%$ out of 334 evaluated plants represented the $20 \%$ of the highest total yield. In France, THÉVENIN (1967) estimated that asparagus yields could be doubled if the field were planted exclusively with the genotypes of the higher yielding fraction. High yielding individuals will therefore contribute to high total yields. Uniformity in association whit high yields can be achieved either by high yielding hybrids or by improved populations with lower genetic variability than current cultivated populations. Elite plants of proven yield and quality that would produce a superior progeny (CURRENCE, 1947) are needed in both cases. Evaluation within population for genetic variability of yield and other economically important traits is essential for current asparagus production. This evaluation implies the observation of individual yield records along many seasons to obtain reliable results (FRANKLIN et al., 1980; Bussel et al., 1987), thus requiring a considerable amount of work and land. Therefore the number of populations to be evaluated is limited by the requirements.

The object of this paper is to evaluate the variability for productive and vegetative characters in three blanched asparagus populations, and to define the most important yield components and their possible use in a selective scheme of elite plants.

\section{MATERIAL AND METHODS}

Three hundred plants of three different populations of Argenteüil cultivars ( $\mathrm{P}_{1}$ from Denmark and $\mathrm{P}_{2}$ and $\mathrm{P}_{3}$ from France) were used as experimental material. The trial was planted during the spring of 1993 in the Experimental Field of the National Rosario University (Rosario, Santa Fe, Argentina) $\left(33^{\circ} 1^{\prime} \mathrm{SL}\right.$; $60^{\circ} 53^{\prime} \mathrm{WL}$ ). Rows were $2,1 \mathrm{~m}$ apart and plants $0,45 \mathrm{~m}$ apart within rows. The trial layout was designed as a randomized complete blocks with three replications (one hundred plants/population/block). Crowns were set at $0,2 \mathrm{~m}$ depth.
The following traits were recorded for each individual plant from 1994, to 1996:

Productive characters: Spear number (SN), mean spear mass (SM), mean spear diameter (SD) and total yield (TY). These variables were recorded during a period of 40 days from the emergence of the first shoot. Harvest was performed three times a week.

Vegetative characters: Date of emergence of the first spear (DE), fern mass (FM), plant height (PH) and stalk number (STN). These variables, except the first, were recorded at the end of the growing season.

The RSQUARE SAS Procedure (SAS Institute, 1982) was used to analyse the principal yield components in each of the growing seasons. The intrapopulation variability for male and female plants was estimated by means of the coefficient of variation (CV) (BANNEROT et al., 1969; NiKOloff et al., 1986). Another indicator of variability was the proportion of plants contributing to $80 \%$ of the total yield (Rовв, 1936; BANNEROT et al., 1969; NiKOlOfF et al., 1986).

In the selection of elite plants two methods were used:

1) Average of total yield per plant along the three seasons of harvest. The limits were set in $350 \mathrm{~g}$ for male plants and $400 \mathrm{~g}$ for female $(X+2 \sigma)$.

2) Grouping obtained by the cluster analysis technique (SAS Tree Procedure, 1982) as a function of total yield, the spear mean mass and the spear number.

The phenotypic correlation between vegetatively and yield related traits were calculated in search of an easier measure of total yield. Those traits which did not present a normal distribution were transformed by $\sqrt{x}+\sqrt{x+1}$ (SOKAL and ROHLF, 1981).

\section{RESULTS AND DISCUSSION}

\subsection{Productive characters}

Multiple regression analysis showed that among the three yield components recorded SN and SM were the most important ones, the values for the three harvest seasons being $R^{2}=0.968, R^{2}=0.963$ and $R^{2}=0.967$, respectively. The balance between both variables was responsible for the lack of yield differences between male and female plants (Table 1) in all the populations and years, as well as the number of plants contributing to $80 \%$ of the total yield (Table $2 \mathrm{~b}$ ) by the compensation between spear number and spear mass in each sex. This fact supports the idea that a higher yield is not exclusive of male plants, in agreement with THÉvENIN (1967), who worked with Argenteüil populations too, and found that the yield of pistilate plants was not higher and with LEY et al. (1976), who attributed the importance of female 
plants in asparagus crop to their superior spear diameter. Maximum yields came from plants having many large spears, whereas plants with many small spears did not produce high yields due to their small spear diameter. Consequently, plants with few large spears failed to produce high yields.

As it was expected in an ageing asparagus field crop, TY increased progressively along the three seasons (Table 1). Since SM got its maximum gains in the second year; it follows that TY increased is due to increases in SN. SD exhibited a similar behaviour to that of SM, indicating that both variables are highly correlated $(\mathrm{r}=0.87 ; \mathrm{r}=0.91$ and $\mathrm{r}=0.84 ; \mathrm{p}<0.001$ for 1994, 1995 and 1996 respectively). Considering the shape of a spear like a cylinder, the SM would be proportional to the SD (LEY et al., 1976). Nevertheless SM is somewhat easier to measure than SD.

Productive traits showed a wide range of variation. The CV's have been used as a measure of uniformity in asparagus trials. In the three populations, independently of the sex of the individual plant, the highest coefficient of variation corresponded to TY and SN (Table 2a), specially in 1995 and 1996. High CV's have also been reported by NIKOLOFF et al., (1986) in a study conducted in New Zealand.

The analysis of the CV indicates the existence of a differential behaviour of the variables since TY and SN increased in the second harvest year while SM and SD didnt (Table 2a). This is probably due to the fact that the spear diameter is related to the size of the crown buds, which depends on the fern growth (TIEDJENS, 1924; BLASBERG, 1932) and consequently on the amount of available carbohydrates. If the growing conditions of the asparagus field are optimum the crowns would have the necessary reserves from the first harvest year. This situation point out that SM and SD could be used in a program of early selection.

The increase of TY and SN in the three populations showed that the potentiality in these characters is not expressed in the first year, therefore selection for them would be inefficient. The result is that in the first year the number of plants integrating the superior group would be higher than in the following years.

An alternative indicator of variability is the proportion of plants that make only a small contribution to the yield. In our trial, for the first harvest season almost $69 \%$ of the plants contributed $80 \%$ of the total yield, while this value decreased for the other periods (Table 2b).

Nine male and eight female plants were selected based on average TY. The average yields for each population and sex in the three seasons are shown in table 3. 
Table 2a. Coefficients of variation for productive characters in the three years of evaluation

\begin{tabular}{|c|c|c|c|c|c|c|c|c|c|c|c|c|c|c|c|c|c|}
\hline & \multicolumn{6}{|c|}{$P_{1}$} & \multicolumn{6}{|c|}{$\mathrm{P}_{2}$} & \multicolumn{5}{|c|}{$P_{3}$} \\
\hline & \multicolumn{2}{|c|}{1994} & \multicolumn{2}{|c|}{1995} & \multicolumn{2}{|c|}{1996} & \multicolumn{2}{|c|}{1994} & \multicolumn{2}{|c|}{1995} & \multicolumn{2}{|c|}{1996} & \multicolumn{2}{|c|}{1994} & \multicolumn{2}{|c|}{1995} & 1996 \\
\hline & $\mathrm{MP}$ & FP & $\mathrm{MP}$ & FP & $\mathrm{MP}$ & $\mathrm{FP}$ & MP & FP & $\mathrm{MP}$ & FP & MP & $\mathrm{FP}$ & $\mathrm{MP}$ & FP & MP & FP & MP FP \\
\hline Total yield (g) & 47.3 & 45.5 & 65.7 & 58.1 & 62.1 & 58.7 & 44.5 & 44.8 & 57.1 & 59.5 & 54.3 & 53.4 & 49.7 & 54.0 & 60.4 & 67.2 & $55.1 \quad 64.9$ \\
\hline Spear Number & 36.4 & 36.9 & 62.2 & 52.9 & 60.2 & 55.5 & 37.8 & 36.0 & 57.0 & 55.3 & 50.3 & 58.8 & 41.1 & 38.9 & 57.6 & 58.2 & $52.4 \quad 56.0$ \\
\hline Spear Mass (g) & 36.3 & 41.2 & 35.3 & 33.6 & 36.1 & 32.6 & 43.7 & 44.2 & 40.8 & 45.5 & 34.1 & 36.2 & 37.8 & 48.2 & 45.8 & 45.8 & $48.3 \quad 49.2$ \\
\hline Spear Diameter (mm) & 22.3 & 29.7 & 19.2 & 20.7 & 18.4 & 18.5 & 26.8 & 30.9 & 22.4 & 26.9 & 19.2 & 19.7 & 24.3 & 31.3 & 23.9 & 26.1 & $20.8 \quad 23.9$ \\
\hline
\end{tabular}

MP: Male Plants; FP: Female Plants.

Table 2 b. Proportion of plants contributing $80 \%$ of the total yield in the three years

\begin{tabular}{|c|c|c|c|c|c|c|c|c|c|}
\hline \multirow[t]{2}{*}{ Population } & \multicolumn{3}{|c|}{ Proportion of plants } & \multicolumn{3}{|c|}{$\begin{array}{l}\text { Yield of male plants contibuting } \\
80 \% \text { of total yield }\end{array}$} & \multicolumn{3}{|c|}{$\begin{array}{l}\text { Yield of female plants } \\
\text { contributing } 80 \% \text { of total yield }\end{array}$} \\
\hline & 1994 & 1995 & 1996 & 1994 & 1995 & 1996 & 1994 & 1995 & 1996 \\
\hline & 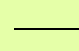 & $-\%$ & - & & & & & & \\
\hline P1 & 68.9 & 57.2 & 58.6 & 93.15 & 194.80 & 320.74 & 86.70 & 221.03 & 339.71 \\
\hline P2 & 68.9 & 58.1 & 59.8 & 106.98 & 224.73 & 372.56 & 96.38 & 198.95 & 336.06 \\
\hline P3 & 67.9 & 56.3 & 58.8 & 102.81 & 249.50 & 404.13 & 95.25 & 222.85 & 394.73 \\
\hline
\end{tabular}

Table 3. Number of the elite plants selected by mean yield values

\begin{tabular}{llcccccc}
\hline $\begin{array}{l}\text { Popu- } \\
\text { lation }\end{array}$ & Sex & $\begin{array}{c}\text { N. of } \\
\text { plants }\end{array}$ & $\begin{array}{c}\text { Yield } \\
94\end{array}$ & $\begin{array}{c}\text { Yield } \\
95\end{array}$ & $\begin{array}{c}\text { Yield } \\
96\end{array}$ & $\begin{array}{c}\text { Mean } \\
\text { yield }\end{array}$ \\
\hline \multirow{2}{*}{ P1 } & Male & 4 & 72.21 & 304.50 & 690.50 & 363.64 \\
& Female & 2 & 83.94 & 388.50 & 743.50 & 419.00 \\
P2 & Male & 1 & 187.56 & 339.00 & 587.50 & 371.35 \\
& Female & 3 & 122.84 & 395.00 & 533.50 & 414.92 \\
P3 & Male & 4 & 46.26 & 374.00 & 523.50 & 352.52 \\
& Female & 3 & 190.51 & 482.00 & 458.50 & 432.73 \\
\hline
\end{tabular}

A larger number of plants was selected by the cluster analysis but included the same selected ones mentioned above (Figure 1).

In the search for elite plants, an increased work is required so that less costly and less time consuming alternative selection criteria are needed. BANNEROT et al. (1969) showed that the populations and the individual plants with superior yields in the first harvest period will be the best along the time. Thus, it would be possible to carry out a program of selection by yield components considering SM in the first year because this character expresses its potentiality since this stage. In our trial the male plants with a mean value over $14 \mathrm{~g}$ and female over $16 \mathrm{~g}$ were selected $(\mathrm{X}+2 \sigma)$.
These limits depend on the populations variability and the selective pressure practised. This selection would reduce in $60 \%$ the number of plant to evaluate in the second year. In this moment the selection would be practised by SN (over 12 for the male plant and over 10 for female plants), considering also the values of $X+2 \sigma$. This would strongly reduce the number of plants to evaluate in the third year (17 male plants and 30 female plants in our case).

The plants selected by spear mass (SM) in the first harvest season and by spear number (SN) in the second harvest season were the most highly productive during the third harvest period. In addition, to begin the plant selection in the first harvest season (early selection) would reduce in one year the total period of evaluation.

\subsection{Vegetative traits}

The date of emergence of the first spear was similar in the three populations with a reduced variation in each one and lower values in the first harvest period (Table 4). This situation is probably related to the fact that the buds of the younger plants are active at lower temperatures than the buds of the older ones. Rовв (1984) found that the temperature threshold for bud break varies with age and cultivar; 1- and 2-yearold plants produce spears earlier in spring than older plants and some varieties are earlier than others. 

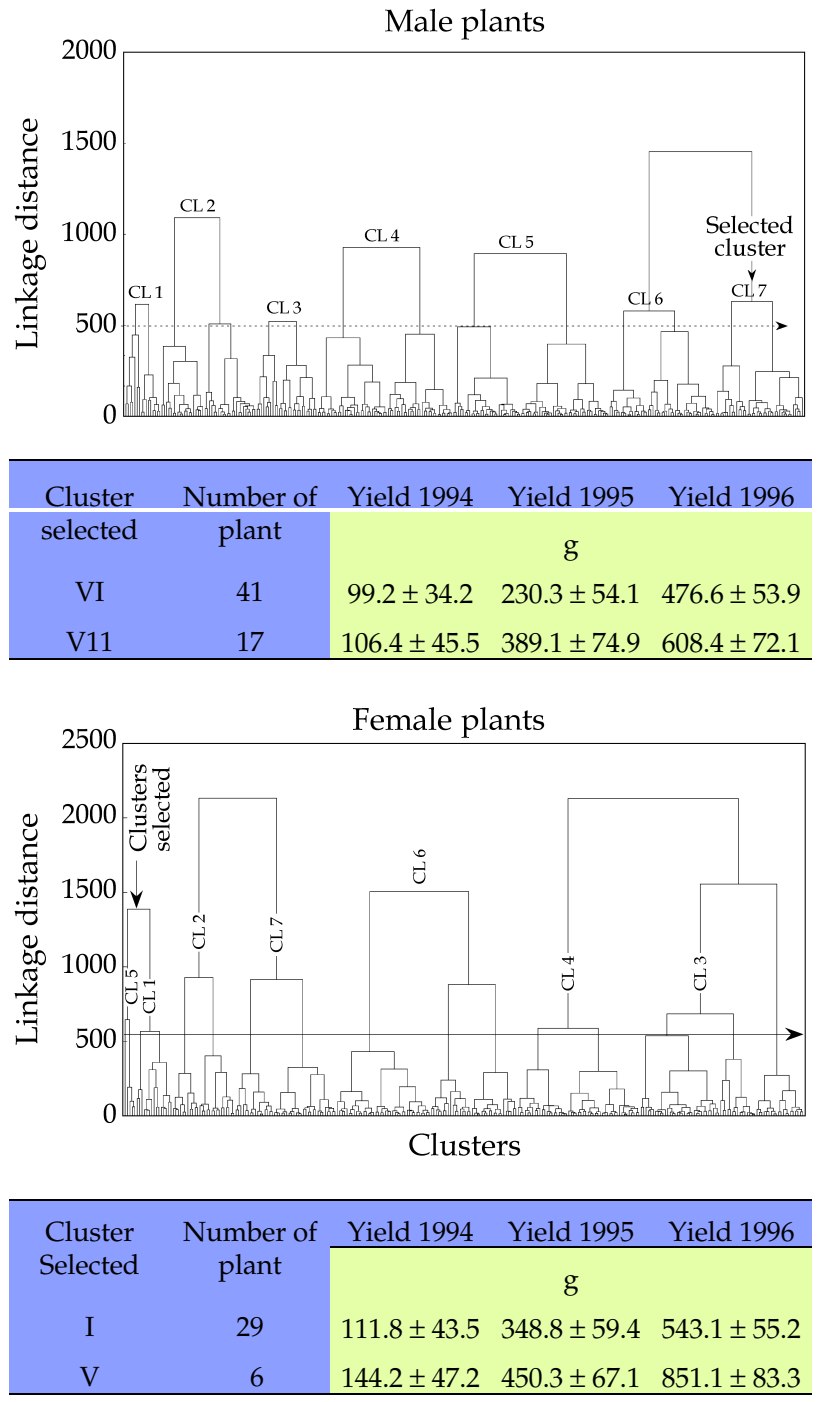

Figure 1. Cluster analysis for male and female plants.

The fern mass is determined by plant height and the stalk number produced during the growth seasons $(\mathrm{r}=0.62$ and $\mathrm{r}=0.58 ; \mathrm{p}<0.001$ for $\mathrm{SN}$ and $\mathrm{PH}$, respectively) and is also correlated positively and significantly with TY $(r=0.58 ; \mathrm{p}<0.01)$. Population 2 showed the smallest values for FM (Table 4), because of the low stalk number produced throught the growing seasons.

\section{CONCLUSIONS}

1. The methodology proposed would result in the same selected elite plants as the customary method but with the advantage of lowering in one year the harvest period, as well as the number of plants to be tested. This fact allows for the evaluation of an

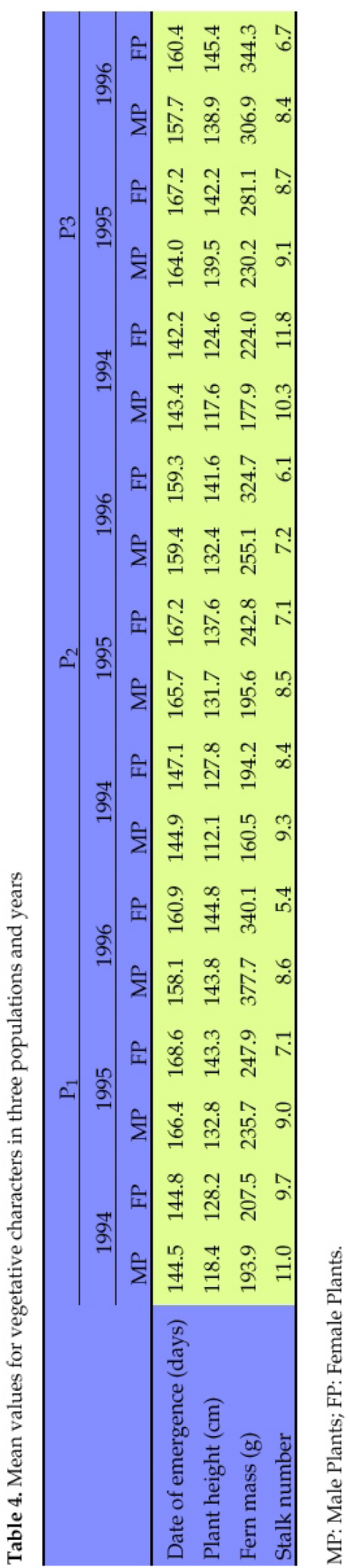

Bragantia, Campinas, 59(1), 21-26, 2000 
increased number of populations arranging them at regular intervals. Thus, it makes it easier to be performed by breeders.

In relation to the vegetative variables, the correlation coefficient between fern weight and total yield was not high enough to be used as yield indicator. Therefore these variables would not be useful as secondary characters in the selection of elite plants.

\section{REFERENCES}

BANNEROT, H.; DERIEUX, M.; THÉVENIN, L.; ARNOUX, J. Résultats d'un essai comparatif de populations dasperge. Annales de lAméliorioration des Plantes, Paris, v.19, n.3, p.289-324, 1969.

BLASBERG, C.H. Phases of the anatomy of seedling asparagus. Botanical Gazette, Chicago, v.94, p.206214, 1932.

BUSSEL, W.T.; BRASH, D.W.; STIEFEL, W. Site variation in percentage of saleable yield of asparagus. Proceedings of Agronomy Society of New Zealand, Wellington, v.17, p.19-20, 1987.

CURRENCE, T.M. Progeny tests of asparagus plants. Journal of Agricultural Research, Washington D.C., v.74, n.3, p.65-76, 1947.

ELLISON, J.H.; SCHEER, D.H. Yield related to brush vigor in asparagus. Proceedings of the American Society for Horticultural Science, Alexandria, v.73, p.339-344, 1959.

FRANKLIN, S.J.; BUSSELL, W.T.; COX, I.T.; TATE, G.K. Asparagus establishment and management for commercial production. AgLink HPP125, Wellington, New Zealand, Ministry of Agriculture and Fisheries, 1980. p.25.
HUYSKES, J.A. The value of comparative tests of progenies from open-pollinated female asparagus plants. Euphytica, Dordrecht, v.8, p.141-144, 1959.

LEY, J.P.; MONGET, M.; THÉVENIN, I. Lamélioration de lasperge (Asparagus officinalis L.): application conjointe de méthodes statistiques descriptives et inférentielles a lutilisation raisonnée des différences de production entre plantes mâles et femelles. Annales de lAmélioration des Plantes, Paris, v.26, n.4, p.675-716, 1976.

MOON, D.M. Yield potential of Asparagus officinalis L. New Zealand Journal of Experimental Agriculture, Wellington, v.4, p.435-438, 1976.

NIKOLOFF, A.S.; ENSOR; P.; PALMER; T.P.; WALLACE, A.R. Between plant variation of asparagus cultivars. New Zealand Agronomy Society Special Publication, Wellington, v.5, p.49-54,1986.

ROBB, A.R. Physiology of asparagus (Asparagus officinalis) as treated to the production of the crop. New Zealand Journal of Experimental Agriculture, Wellington, v.12, p.251-260, 1984.

ROBB, O.J. Some observations on individual asparagus plants records. Scientific Agriculture, Chicago, v.17, n.3, p.144-145, 1936.

SOKAL, R.R.; ROHLF, F.G. Biometry, $2^{\text {nd }}$ ed. San Francisco. Freeman, 1981. p.458

SAS INSTITUTE. SAS users guide: Statistics. Cary, NC. SAS Institute, 1982. 583p.

THÉVENIN, L. Les problèmes damélioration chez Asparagus officinalis L. I Biologie et amélioration. Annales de lAmélioration des Plantes, Paris, v.17, n.1, p.3366, 1967.

TIEDJENS, V.A. Some physiological aspects of $A s-$ paragus officinalis L. Proceeding of the American Society for Hortcultural Science, Alexandria, v.21, p.129-140, 1924. 